\title{
Solar-Wind Renewable Energy System for Off-Grid Rural Electrification in Ecuador
}

\author{
Julio Barzola, Mg. ${ }^{1}{ }^{2}$, Mayken Espinoza, MEF ${ }^{2},{ }^{3}$, Christian Pavón, MEF ${ }^{4}$ and Fausto Cabrera, Mg. ${ }^{1}$ IUniversidad Laica \\ VICENTE ROCAFUERTE de Guayaquil, Ecuador, jbarzolam@ulvr.edu.ec, fcabreram@ulvr.edu.ec ${ }^{2}$ Escuela Superior \\ Politécnica del Litoral, Ecuador, masespin@espol.edu.ec, jjbarzol@espol.edu.ec \\ ${ }^{3}$ Lund University, Sweden, Mayken.Espinoza_Andaluz@energy.lth.se \\ ${ }^{4}$ Universidad de Guayaquil, Ecuador, christian.pavonb@ug.edu.ec
}

\begin{abstract}
The increasing world population, and therefore the increasing of the energy demand bring us to the scenario in which the energetic solutions have to be supported by the renewable energy sources, i.e., solar energy, wind energy, tidal energy, etc. Due to the geographic location of Ecuador, these types of energy sources can be considered during the analysis, design and implementation of a rural electrification system. An off-grid electrification is helpful, especially for providing electrical energy in remote areas. The purpose of this work is to analyse and propose a suitable energetic off-grid system solution for rural electrification in a selected county placed in Ecuador. This study is based on insitu measurements of energy consumption as well as on the quantification of possible energy sources, i.e., solar and wind energy. This analysis is carried out with the help of a simulation tool. Considering the real obtained data, the electric load profile for a community is estimated and a complete system is proposed. Additionally, technical and economic details of a Wind-Solar energy system are presented.

Keywords-- Solar-Wind, Renewable energy, Off-Grid energy
\end{abstract} system, Rural electrification.

Digital Object Identifier (DOI):

http://dx.doi.org/10.18687/LACCEI2016.1.1.056

ISBN: 978-0-9822896-9-3

ISSN: 2414-6390

$14^{\text {th }}$ LACCEI International Multi-Conference for Engineering, Education, and Technology: "Engineering Innovations for Global Sustainability", 20-22 July 2016, San José, Costa Rica. 


\title{
Solar-Wind Renewable Energy System for Off-Grid Rural Electrification in Ecuador
}

\author{
Julio Barzola, Mg. ${ }^{1,2}$, Mayken Espinoza, $\mathrm{MEF}^{2,3}$, Christian Pavón, $\mathrm{MEF}^{4}$ and Fausto Cabrera, Mg. ${ }^{1}$ \\ ${ }^{1}$ Universidad Laica VICENTE ROCAFUERTE de Guayaquil, Ecuador, jbarzolam@ulvr.edu.ec, fcabreram@ulvr.edu.ec \\ ${ }^{2}$ Escuela Superior Politécnica del Litoral, Ecuador, masespin@espol.edu.ec, jjbarzol@espol.edu.ec \\ ${ }^{3}$ Lund University, Sweden, Mayken.Espinoza_Andaluz@energy.lth.se \\ ${ }^{4}$ Universidad de Guayaquil, Ecuador, christian.pavonb@ug.edu.ec
}

\begin{abstract}
The increasing world population, and therefore the increasing of the energy demand bring us to the scenario in which the energetic solutions have to be supported by the renewable energy sources, i.e., solar energy, wind energy, tidal energy, etc. Due to the geographic location of Ecuador, these types of energy sources can be considered during the analysis, design and implementation of a rural electrification system. An off-grid electrification is helpful, especially for providing electrical energy in remote areas.

The purpose of this work is to analyze and propose a suitable energetic off-grid system solution for rural electrification in a selected county placed in Ecuador. This study is based on in-situ measurements of energy consumption as well as on the quantification of possible energy sources, i.e., solar and wind energy. This analysis is carried out with the help of a simulation tool. Considering the real obtained data, the electric load profile for a community is estimated and a complete system is proposed. Additionally, technical and economic details of a Wind-Solar energy system are presented.
\end{abstract}

Keywords-- Solar-Wind, Renewable energy, Off-Grid energy system, Rural electrification.

\section{INTRODUCTION}

The interest and development of new standards for smart electric systems integrating renewable energies have been increasing during the last years [1][2]. These systems are constitutive of an infrastructure that can provide with electric load for different applications such as smart home, electric vehicles, irrigation systems and others [3][4]. In addition, the electrical energy obtained from a microgrid, off-grid or gridconnected can be managed in a more efficient manner according to [5].

Due to their characteristics, the applicability of the offgrid systems are on the rise worldwide. For developing countries, providing energy access is an important driver for off-grid renewable energy systems. The mentioned systems are, in many cases, the most economical solution for people without access to electricity [6], especially in remote areas.

There have been several studies related to the Hybrid Power System (HPS) [7-13] considering different characteristics of the systems and demand. However, in this study, to decrease the oil dependence and propose a complete friendly environmental system, no diesel generator is considered during the corresponding design. Additionally, the data used for the present study are obtained in-situ, which give us a very realistic approximation.

Digital Object Identifier (DOI): http://dx.doi.org/10.18687/LACCEI2016.1.1.056 ISBN: 978-0-9822896-9-3

ISSN: $2414-6390$
In Ecuador, according to the Population and Housing Census conducted in 2010, it was estimated that the total percentage of households with electricity in rural areas is $89.03 \%$ [14] and in border areas, electricity supply is still very precarious [15].

According to a study in 2014 , the generation of electricity in Ecuador coming from solar and wind resource, considering the total energy supplied, are about $0.07 \%$ and $0.32 \%$, respectively [16]. Considering the geographic location of the country, there are have been several efforts to start taking advantage of these resources efficiently during the last years. For example, for power generation purposes the Solar and Wind Atlas were published in 2008 and 2013, respectively [17].

The implementation of a complete off-grid rural electrification system is not suggested if a feasibility analysis of the energy system is not effected. Additionally, before the implementation and start up, several variables such as material cost, operating cost, benefits, etc. must be considered. In order to analyze such feasibility, system scale modeling appears a powerful tool to design and validate the possibility of building the off-grid system.

The computational tool applied in this work is HOMER. The different parts of the system are adapted according to the specifications of electric load demand required. Such electric demand is, as mentioned, based on real obtained data. Finally, a generation system is proposed. More detail information about the design process and analysis is given in the corresponding sections.

The rest of the paper is divided as follows: Section II is mainly dedicated to general information about the process for the modeled system and characteristics of the selected place. Section III presents the characteristics of the model based on the computational tool used. Simulation results and discussions are given in Section IV. Finally, the conclusions of the present study are presented in Section V.

\section{BACKGROUND INFORMATION}

This research is carried out following several steps, starting with the data collection (from weather stations as well as electricity consumption habits) to the analysis and simulation of the system considering the different parts of the off-grid system, as depicted in Fig. 1.

14 ${ }^{\text {th }}$ LACCEI International Multi-Conference for Engineering, Education, and Technology: "Engineering Innovations for Global Sustainability”, 20-22 July 2016, San José, Costa Rica. 


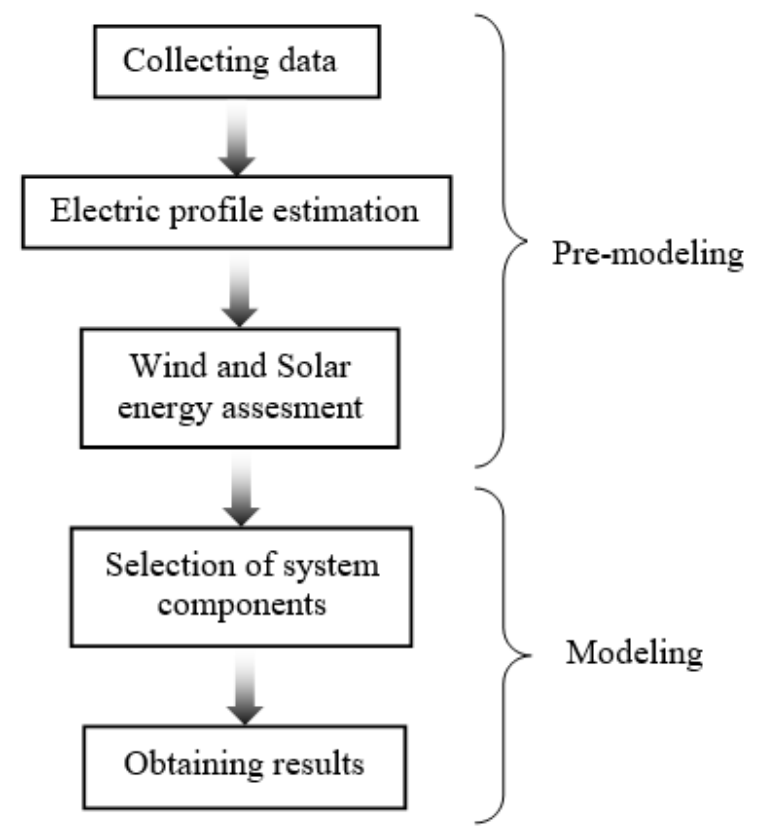

Fig. 1 Flow chart showing the steps followed in the present study.

Characteristics and limitations for each step presented in Fig. 1 are given in the next sections.

\section{A. Location and population}

Ecuador is an oil producing country with a population estimated over 16 million in 2014. There are twenty-four provinces, and the total electricity coverage is $97.04 \%$. However, there are three provinces with the lowest coverage: Napo, 86.97\%; Pastaza, 87.58\% and Santa Elena, 90.81\% [16].

For this work, the selected rural parish is Atahualpa, a small village in the Santa Elena county in the Ecuadorian province of Santa Elena [18][19]. The details of the village are listed in table I.

TABLE I

\begin{tabular}{|c|c|}
\hline Particulars & Details \\
\hline Parish name & Atahualpa \\
\hline County & Santa Elena \\
\hline Province & Santa Elena \\
\hline Country & Ecuador \\
\hline Geographical location & Ecuadorian Coast \\
\hline Latitude & $2^{\circ} 19^{\prime} 04.1{ }^{\prime \prime} \mathrm{S}$ \\
\hline Longitude & $80^{\circ} 46^{\prime} 41.8^{\prime \prime} \mathrm{W}$ \\
\hline Elevation (in meters) & 47 \\
\hline Rivers available & 0 \\
\hline Number of households & 812 \\
\hline Total population (approx.) & 3600 \\
\hline Members per family (average) & 5 \\
\hline Unsatisfied basic services (\%) & 75.6 \\
\hline Weather & Arid \\
\hline Season & Rainy and dry \\
\hline Rainfall (Annual, in mm) & 150 \\
\hline Temperature (in ${ }^{\circ} \mathrm{C}$ ) & $21-40$ \\
\hline
\end{tabular}

\section{B. Electric Load profiles estimation}

In previous studies, some authors have estimated the electric charge in remote areas. For instance, in [20] the electrical load to domestic purposes in a village has considerable low energy consumption - energy lights (CFL), radio, ceiling fan and table fan. A similar study has considered a remote residential home with an electrical load of $2 \mathrm{~kW}$ peak to perform the corresponding analysis [21].

In this study, Atahualpa has remote residential homes which lack access to the utility grid. Therefore, in order to analyze the efficiency and reliability of the power generation system, a total electric load of twelve homes has been considered. In each house, a load of $0.97 \mathrm{~kW}$ peak is required. Consequently, taking into account the mentioned demand considerations, a group of twelve homes requires up to 11.61 $\mathrm{kW}$ peak, approximately.

A typical sample of the daily load profile is shown in Fig. 2. From the load profile, it can be noticed that the load requirement varies throughout the day. Furthermore, it can be observed that the maximum demand occurs during the evening hours, i.e., from $6 \mathrm{pm}$ to $10 \mathrm{pm}$.

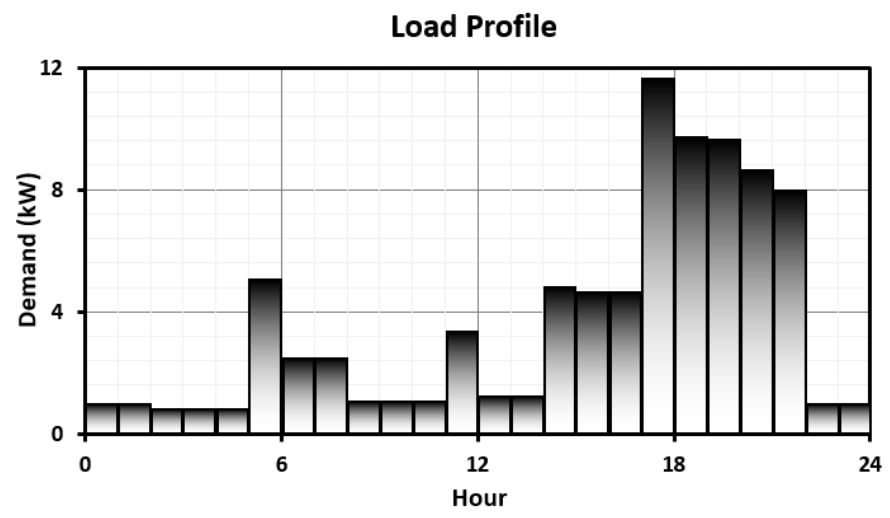

Fig. 2 Daily energy demand for residential homes in Atahualpa.

The electric load of each residential building was estimated based on previous general and particular studies [19][22]. Table II shows the electrical equipment used per family, which is composed of five members.

\section{Solar energy potential assessment}

For this study, the solar radiation profile of Atahualpa, Santa Elena, (2 $\left.2^{\circ} 9^{\prime} 04.1^{\prime \prime} \mathrm{S}, 80^{\circ} 46^{\prime} 41.8^{\prime \prime} \mathrm{W}\right)$ is considered. Solar radiation data are obtained in situ from weather stations previously installed by a research project related to thermal insulators and building materials [4][23].

The solar radiation data were estimated to range between $3.99 \mathrm{kWh} / \mathrm{m}^{2}$ and $5.85 \mathrm{kWh} / \mathrm{m}^{2}$. The annual average was scaled to be $5.05 \mathrm{kWh} / \mathrm{m}^{2} / \mathrm{day}$, and the average clearness index was found to be 0.50 with some variations along the year. Fig. 3 shows the solar radiation profile over a one-year period.

14 ${ }^{\text {th }}$ LACCEI International Multi-Conference for Engineering, Education, and Technology: "Engineering Innovations for 
TABLE II

ESTIMATE ELECTRICITY DEMAND FOR A TYPICAL HOME

\begin{tabular}{|c|c|c|c|c|c|}
\hline Qty & Load & $\begin{array}{c}\text { Power } \\
(\text { watts })\end{array}$ & $\begin{array}{c}\text { Total Power } \\
(\mathrm{kW})\end{array}$ & Hrs/Day & $\begin{array}{c}\mathrm{kW}- \\
\text { hrs/Day }\end{array}$ \\
\hline 8 & $\begin{array}{c}\text { Low-energy } \\
\text { lights (CFL) }\end{array}$ & 23 & 0.18 & 6 & 1.10 \\
\hline 1 & $\begin{array}{c}\text { Computer } \\
\text { equipment }\end{array}$ & 300 & 0.3 & 6 & 1.8 \\
\hline 1 & TV & 120 & 0.12 & 8 & 0.96 \\
\hline 1 & Radio & 80 & 0.08 & 2 & 0.16 \\
\hline 1 & Blender & 350 & 0.35 & 0.25 & 0.09 \\
\hline 1 & $\begin{array}{c}\text { Smoothing } \\
\text { iron }\end{array}$ & 550 & 0.55 & 1.5 & 0.83 \\
\hline 2 & Table Fan & 15 & 0.03 & 8 & 0.24 \\
\hline 1 & Fridge & 250 & 0.25 & 8 & 2.00 \\
\hline \multicolumn{2}{|c|}{ Subtotal } & & 1.86 & & 7.18 \\
\hline \multicolumn{2}{|r|}{ Total (12 houses) } & & 22.37 & & 86.12 \\
\hline
\end{tabular}

It can be noticed that more solar irradiance is received from November to May while less solar irradiance is to be expected between June and October, with the minimum value during August. The solar irradiance variation is a key variable to consider in order to ensure continuity of service power required by electrical load.

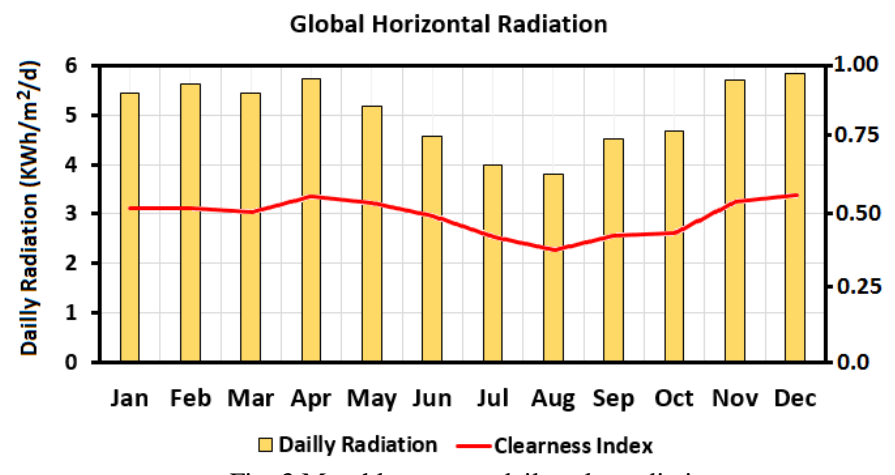

Fig. 3 Monthly average daily solar radiation.

\section{Wind energy potential assessment}

Wind speed data are obtained in situ from weather stations at $4 \mathrm{~m}$ of height. The wind speed data are estimated to range between $2.6 \mathrm{~m} / \mathrm{s}$ and $3.27 \mathrm{~m} / \mathrm{s}$, and the annual wind speed average is scaled to $2.84 \mathrm{~m} / \mathrm{s}$. Fig. 4 shows the wind speed profile over a one-year period.

Considering the measured data, higher wind speed values are expected from June to March, while lower wind speed values are obtained during April and May. Due to the monthly average wind speeds in Atahualpa are relatively low, the greater contribution of power generation in the system is concerned with the PV array.

In order to extrapolate the measurements to a height of 10 $m$ the Hellmann's Exponential Law [10] is used:

$$
\frac{V(z)}{V\left(z_{r}\right)}=\left(\frac{z}{z_{r}}\right)^{\alpha}
$$

Where $V(z)$ is wind speed estimated at desired height $z$, $V\left(z_{r}\right)$ is the wind speed at boundary layer height $z_{r}$, and $\alpha$ is the power-law index. For Atahualpa, given the characteristics of the region, $\alpha$ is established equal to 0.6 [24]. Therefore, the estimated wind speed to a height of $10 \mathrm{~m}$ is approximately $4.92 \mathrm{~m} / \mathrm{s}$. For the proposed system, the wind turbine is sized based on this mentioned speed.

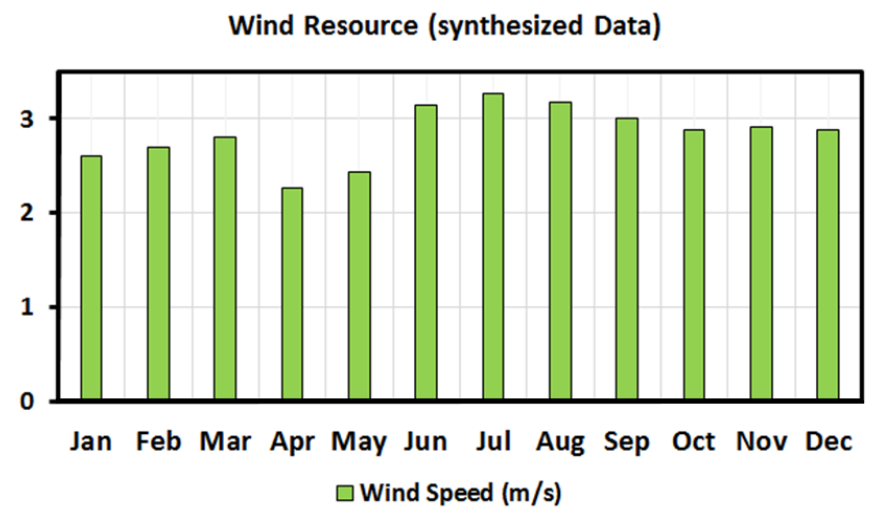

Fig. 4 Monthly average wind speed profile at Atahualpa.

\section{SYSTEM DESCRIPTION AND DESIGN SPECIFICATION}

The proposed Power System (PS) is mainly constituted of wind turbines and Photovoltaic (PV) arrays. Unlike other studies of HPS [7-13] where diesel generator is usually used as a back-up unit for peak load, poor resource periods or/and reduce Cost Of Electricity (COE), the present work only considers battery bank as a back-up unit and Storage Energy Systems.

This PS, based on Solar-Wind Renewable Energy for OffGrid Rural Electrification, can be used to estimate the system performance that excludes the dependency of fossil as backup. This can be achieved since this system uses $100 \%$ real weather data from renewable energy sources.

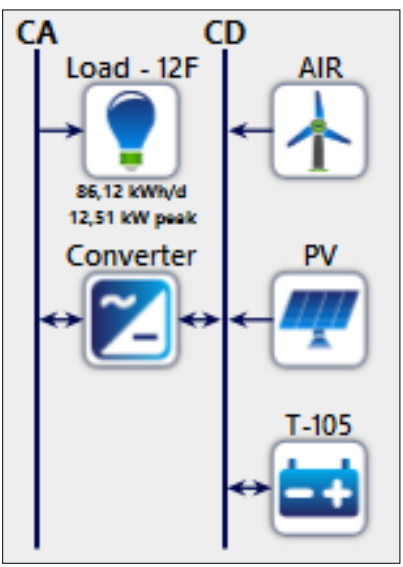

Fig. 5 Schematic of the PS design using HOMER.

$14^{\text {th }}$ LACCEI International Multi-Conference for Engineering, Education, and Technology: "Engineering Innovations for 
For this study, the computational tool used to evaluate design options and sizing the components of the PS is HOMER. It is a computational tool developed in 1992 by the U.S. National Renewable Energy Laboratory (NREL). HOMER simulates and optimizes both off-grid and gridconnected power systems through three principal tasks: simulation, optimization, and sensitivity analysis [25][26]. The configuration of the PS is shown in Fig. 5. There are four main components to be considered, i.e., wind turbines, PV modules, batteries and converters.

\section{A. Homer Simulation Model}

In order to determinate technical feasibility and life-cycle cost of the PS, HOMER performs an hourly time series simulation based on the components selected by the designer. In this instance, the software carries out the energy balance calculation over one year through the system configuration. The system configuration is modified by testing the energy balance considering variations of the components in number and size. Then, it determines the best feasible system configuration that can adequately serve the total electrical load demand and satisfy any other constraints imposed by the designer. Additionally, it should be noted that HOMER simulates the PS based on several parameters such as capital cost, replacement cost, operational and maintenance (O\&M) cost, capacity and lifetime [26].

Moreover, during the optimization process, HOMER analyzes each possible configuration performance during the simulation process, and come out with a list of optimal configurations sorted based on the Total Net Present Cost (TNPC). Considering the information obtained using the tool, the designer can perform configuration comparisons vs. lowest and highest TNPC [26]. The criteria for selecting the optimal PS configuration is the lowest TNPC.

On the other hand, the list of configurations based on TNPC is varied depending on sensitivity variables such as global solar and wind speed. The mentioned variations can be selected by the same designer. In the sensitivity analysis process, HOMER repeats the optimization process for every selection of sensitivity variable for the PS. Finally, the list of various configurations of PS is displayed from the lowest to the highest TNPC [26].

Characteristics for each selected component of the system applied in the analysis are given in the next sections.

\section{B. PV array}

The PV panels are connected in series. The capital cost for each capacity (kW) is $\$ 3000$ and the replacement cost is $\$ 2500$. These costs include shipping, tariffs, installation and dealer markups. The O\&M cost is assumed to be $\$ 10 /$ year for each $\mathrm{kW}$.

Considering the location of Atahualpa, the array slope angle is set to $10^{\circ}$ and the array azimuth is $0^{\circ}$. The azimuth is referring to the North direction. The lifetime for this PV array system is 25 years with a derating factor $\left(f_{\mathrm{PV}}\right)$ of $90 \%$, and the ground reflectance is $20 \%$. The orientation of the array is fixed, i.e., no tracking system is considered.

It should be noted that this PV array would only generate electricity at day time, i.e., from 6 AM until 6 PM. At night, there is no electricity generated from this source, and therefore; the output from solar is $0 \mathrm{~W}$. At night, the battery bank will take over the task [5]. Given the measured data, the power generated by PV array is more than the generated by wind turbines at Atahualpa due to better solar insolation.

\section{Wind turbine}

Due to monthly average wind speeds are relatively low in Atahualpa, small scale wind turbines used for off-grid applications in remote areas are considered. These turbines can be used to generate electricity to charge batteries and to power DC or AC loads [27].

Based on an average wind speed $2.84 \mathrm{~m} / \mathrm{s}$ (height $=4 \mathrm{~m}$ ) and $4.92 \mathrm{~m} / \mathrm{s}$ to a hub height of $10 \mathrm{~m}$, the SW AIR X Wind Turbine is selected. This can be installed in oceanic areas, which is an advantage because Atahualpa is very close to the Pacific Ocean.

One turbine SW AIR X gives a $0.55 \mathrm{~kW}$ of DC output. However, the amount of electricity generated depends on availability and variations of the wind speed, i.e., according to a particular power curve of the manufacturer.

The cost of one unit is taken as $\$ 1200$, while the replacement and the O\&M cost are considered to be $\$ 1100$ and $\$ 20 /$ year respectively. The lifetime of this turbine is 15 years.

\section{Storage battery bank}

Battery bank is used as a backup unit and Storage Energy Systems. Its main function at the PS is to provide a reliable supply, i.e., maintaining a constant voltage during peak loads or a shortfall in generation capacity [20][26].

The type of battery selected for the PS is Trojan T-105 with nominal voltage of $6 \mathrm{~V}$ and a nominal capacity of 230Ah. The minimum state of charge is $30 \%$ and its round trip efficiency is $85 \%$. It has a lifetime throughput of $845 \mathrm{kWh}$.

The cost for one unit of this battery is $\$ 150$ with the replacement cost of $\$ 130$. The O\&M cost is assumed to be $\$ 10 /$ year for each battery.

The batteries coupled to the system are charged with the excess of electricity when PV-Array and Wind Generator are operating at maximum rated capacity, i.e., under the charging dispatch strategy cycle.

\section{E. Converter}

For this study, the converter at PS is a component that converts electric power from direct current (DC) to alternating current $(\mathrm{AC})$ in a process called inversion. 
The capital cost, replacement cost and O\&M costs of the converter for a $1 \mathrm{~kW}$ system are established as $\$ 300, \$ 250$, and $\$ 10 /$ year, respectively. The lifetime of the converter is 15 years, and inverter efficiency of $90 \%$.

TABLE III

TECHNICAL \& ECONOMIC DETAILS OF SOLAR-WIND ENERGY SYSTEM OPTIMAL CONFIGURATION

\begin{tabular}{|c|c|}
\hline \multicolumn{2}{|c|}{ PV Array } \\
\hline Size & $25 \mathrm{~kW}$ \\
\hline Capital Cost & $\$ 3000 / \mathrm{kW}$ \\
\hline Replacement cost & $\$ 2500 / \mathrm{kW}$ \\
\hline O\&M Cost & $\$ 10 /$ year $/ \mathrm{kW}$ \\
\hline Efficiency & $13 \%$ \\
\hline Lifetime & 25 years \\
\hline Tracking system & No tracking \\
\hline \multicolumn{2}{|c|}{ Wind Generator } \\
\hline Size & 9 turbines \\
\hline Technology/name & SW AIR X \\
\hline Power & $0.55 \mathrm{~kW}$ DC each \\
\hline Hub Height & 18 \\
\hline Capital Cost & $\$ 1200$ each \\
\hline Replacement cost & $\$ 1100$ each \\
\hline O\&M Cost & \$20/year each \\
\hline Lifetime & 15 years \\
\hline \multicolumn{2}{|c|}{ Battery } \\
\hline Size & 180 batteries \\
\hline Technology/name & Trojan T-105 \\
\hline Nominal Capacity & $230 \mathrm{Ah}$ \\
\hline Voltage & $6 \mathrm{~V}$ \\
\hline Min. SOC & $30 \%$ \\
\hline Capital Cost & $\$ 150$ each \\
\hline Replacement cost & $\$ 130$ each \\
\hline O\&M Cost & \$10/year each \\
\hline Round trip & $85 \%$ \\
\hline Lifetime & $845 \mathrm{kWh}$ each \\
\hline \multicolumn{2}{|c|}{ Converter } \\
\hline Size & $12 \mathrm{~kW}$ \\
\hline Capital Cost & $\$ 300 / \mathrm{kW}$ \\
\hline Replacement cost & $\$ 250 / \mathrm{kW}$ \\
\hline O\&M Cost & $\$ 10 /$ year $/ \mathrm{kW}$ \\
\hline Efficiency & $90 \%$ \\
\hline Lifetime & 15 years \\
\hline \multicolumn{2}{|c|}{ Economic Data } \\
\hline Nominal Interest Rate [28] & $9.32 \%$ \\
\hline Annual (2015) Inflation Rate [28] & $3.38 \%$ \\
\hline Project Life Time & 25 years \\
\hline \multicolumn{2}{|c|}{ System Control } \\
\hline Dispatch strategy & Cycle Charging \\
\hline \multicolumn{2}{|c|}{ Electrical Production } \\
\hline PV - Array & $40986 \mathrm{kWh} /$ year $-82.42 \%$ \\
\hline Wind Generator & $8741 \mathrm{kWh} /$ year - $17.58 \%$ \\
\hline Total & $49726 \mathrm{kWh} /$ year \\
\hline
\end{tabular}

\section{RESULTS AND DISCUSSION}

\section{A. Optimization of renewable energy system}

A brief summary of the data for each selected component is shown in Table III. The optimal combination of PS components for our case study is a $25 \mathrm{~kW}$ PV-Array, $9 \mathrm{SW}$ AIR X turbines, $180 \mathrm{~T}-105$ batteries and $12 \mathrm{~kW}$ Inverter with a dispatch strategy of cycle charging (CC). This system consider the wind speed as $2.84 \mathrm{~m} / \mathrm{s}$, i.e., the annual average with a height of $4 \mathrm{~m}$. The most economical (least TNPC) system cost, capital cost and COE for this HPS are \$179928, $\$ 116400$ and $\$ 0.444 / \mathrm{kWh}$, respectively.

It can be noticed that in Ecuador, one residential user of an electric distribution company with consumption greater than $3500 \mathrm{kWh} /$ month must pay $\$ 0.6712 / \mathrm{kWh}$ excluding other taxes [29]. In our study, this HPS generates $49726 \mathrm{kWh}$ per year, i.e., 4143.83 monthly on average, with a COE of $0.444 / \mathrm{kWh}$ and serves the total electric load demand of 12 homes located in remote areas.

Fig. 6 depicts the monthly distribution of the electricity produced in $\mathrm{kW}$ by the PV-Array and Wind Generator. It is evident that the main contribution throughout the year comes from the photovoltaic system. This result agrees with the already mentioned about the wind speed values are not as high in Atahualpa. However, the simulation and optimization denote a contribution of the nine micro-turbines might not be negligible.

The PV-Array produces $40986 \mathrm{kWh} /$ year and operates $4349 \mathrm{~h} /$ year (capacity factor 18.72\%). At this level of operation, the COE of PV System becomes just $\$ 0.15 / \mathrm{kWh}$.

On the other hand, wind generator produces 8741 $\mathrm{kWh} /$ year with a capacity factor of $20.16 \%$ (operating for $8077 \mathrm{~h} /$ year), and the COE of the wind generator is also $\$ 0.15 / \mathrm{kWh}$.

The $23.8 \%$ of the generated electricity, i.e., 11822 $\mathrm{kWh} /$ year, goes unused due to low demand, and is used to feed the dump loads. This is particularly high from November to April when solar irradiance reach high values, and the PV system has a surplus of electrical production. However, a related study [20] presents two possible benefits: PS could have the capability to serve a growing demand in the future; or it could also meet the demand of other nearby homes. Therefore, with increasing demand, the load factor is increased and the $\mathrm{COE}$ will decrease.

\section{B. Consideration of sensitivity variables}

Sensitivity analysis is also performed. Fig. 7 depicts the variation of the $\mathrm{COE}$ through respective sensitivities of wind speed vs. PV capital cost multiplier.

According to data collected in Atahualpa by meteorology station [18], the variation in wind speed is, on average, between 2.27 and $4.67 \mathrm{~m} / \mathrm{s}$. The current maximum PV price is assumed to be $\$ 3000 / \mathrm{kW}$ and the minimum $\$ 1800 / \mathrm{kW}$, considering a future fall in price [30]. 


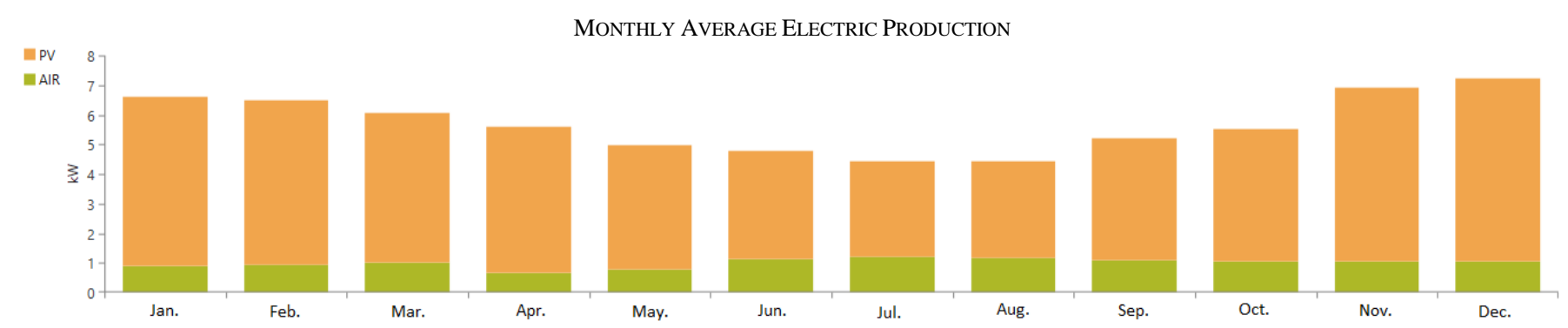

Fig. 6 Monthly average electricity production from the best configuration system.

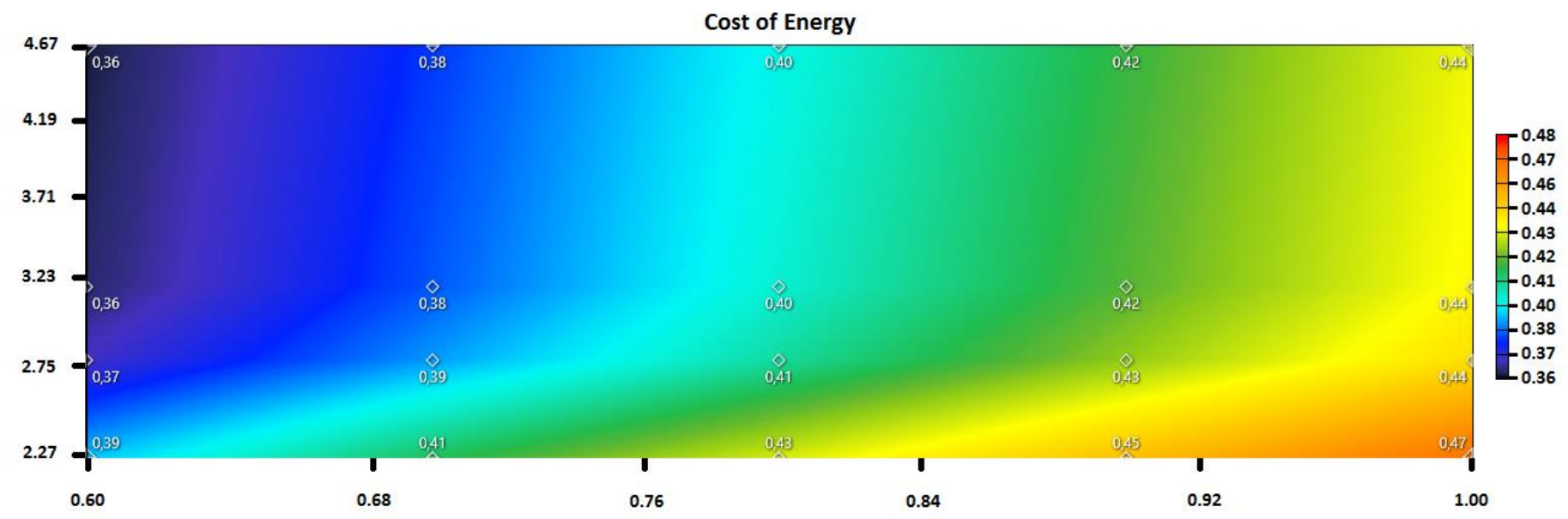

Fig. 7 Surface plot of Cost of Electricity.

It can be noted from Fig. 7, cost of $1 \mathrm{kWh}$ is favored as $\mathrm{PV}$ price decreases and wind speed increases. In the same way, when wind speed increases and PV price decreases, the TNPC of the system will fall. However, the TNPC and COE will be more expensive when the above variations are not carried out.

On the other hand, considering the PV capital cost multiplier $=0.6$, i.e., $\$ 1800 / \mathrm{kW}$ and Wind Speed $=4.67 \mathrm{~m} / \mathrm{s}$; HOMER displayed the best PS configuration with the following characteristics: $25 \mathrm{~kW}$ PV-Array, 8 SW-AIR X turbines, $180 \mathrm{~T}-105$ batteries and $12 \mathrm{~kW}$ Inverter with a dispatch strategy of cycle charging (CC). The TNPC, capital cost and COE are $\$ 146955, \$ 85200$ and $\$ 0.362 / \mathrm{kWh}$, respectively.

The PV-Array produces $40986 \mathrm{kWh} / \mathrm{year}$ and operates $4349 \mathrm{~h} /$ year and its capacity factor is $18.72 \%$. The COE of PV System is $\$ 0.09 / \mathrm{kWh}$. Moreover, wind generator produces $10116 \mathrm{kWh} /$ year with a capacity factor of $26.25 \%$ (operating for $7570 \mathrm{~h} /$ year) and the $\mathrm{COE}$ of the wind generator is $\$ 0.11 / \mathrm{kWh}$.

The excess of electricity is $13186 \mathrm{kWh} /$ year, which is $25.8 \%$ of total energy generated. As showed, varying both the PV capital cost multiplier and wind speed, the PS characteristics are modified.

\section{CONCLUSIONS}

This work presents the optimal design and economically viable hybrid power system solution that is a fully renewablebased. This study is performed using the HOMER software, which provides very efficient tools for our analysis off-grid rural electrification in Atahualpa.

The COE from the optimal HPS configuration that serves the total electric load demand of twelve homes is about $\$ 0.444 / \mathrm{kWh}$. This value is cheaper than $\$ 0.6712 / \mathrm{kWh}$, which is obtained from one residential user of an electric distribution company with consumption greater than the load demand in Atahualpa.

Moreover, if considering sensitive variables, the COE of the PS becomes just $\$ 0.362 / \mathrm{kWh}$. It is noted that, the sensitive configuration of the PS is almost similar to the optimized, it only differs in a wind turbine. In this case, the wind generator provides the greatest support for electricity production, their capacity factor goes from $20.16 \%$ (optimal configuration) to $26.25 \%$ (sensitive configuration). This could be an opportunity to retort this system in other remote locations that have higher levels of wind speeds. On the other hand, the cost of the PV Array may decrease due to state incentives or price in fall. 
In a future work, a comparative analysis of technical and economic parameters of an off-grid PS and grid extension will be performed. So, the breakeven grid extension distance will be determined in order to assess whether the Grid extension is feasible or off-grid system is much more appropriate.

\section{ACKNOWLEDGMENT}

J.B.M. thanks SENESCYT's scholarship for the financial support received during his master studies in Italy.

M.E.A. thanks ESPOL and SENESCYT for the support received during his doctoral studies in Sweden.

\section{REFERENCES}

[1] J. Barzola and L. Rubini, "The telegestore system evolved according OSI model and its performance compared with the new IEEE 1901.2 standard," in 2014 IEEE Central America and Panama Convention (CONCAPAN XXXIV), 2014, pp. 1-4.

[2] J. Barzola, "Hypothetical studio of migration toward IEEE 1901.2 Standard with the existent Italian distribution electric network," University of Rome "Sapienza," 2014.

[3] D. Matamoros, J. Barzola, and M. Espinoza, "Sizing Photovoltaic Irrigation Systems using Meteorological Data," in 8th International Conference on Energy Planning, Energy Saving, Environmental Education, 2015, pp. 220-227.

[4] J. Barzola, F. Cabrera, and M. Espinoza, "On Parameters Testing of an Innovative Mortar Made of Rice Husk to be Used for Housing Walls," in ISES Solar World Congress 2015, 2015, pp. 1-7.

[5] G. Jimènez-Estèvez, R. Palma-Behnke, D. Ortiz-Villalva, O. Nùnez Mata, and C. Silva Montes, "Social SCADA and Approaches to Community Engagement in Isolated Microgrids," IEEE power energy Mag., pp. 6069, 2014.

[6] IRENA, "Off-grid renewable energy systems: Status and methodological issues", Working paper, 2015, pp. 2 - 3.

[7] G. Bekele and G. Tadesse, "Feasibility study of small Hydro/PV/Wind hybrid system for off-grid rural electrification in Ethiopia," Appl. Energy, vol. 97, pp. 5-15, 2012.

[8] N. a B. a Razak, M. M. B. Othman, and I. Musirin, "Optimal sizing and operational strategy of hybrid renewable energy system using HOMER," PEOCO 2010 - 4th Int. Power Eng. Optim. Conf. Progr. Abstr., no. June, pp. 495-501, 2010.

[9] G. Bekele and B. Palm, "Feasibility study for a standalone solar-windbased hybrid energy system for application in Ethiopia," Appl. Energy, vol. 87, no. 2, pp. 487-495, 2010.

[10] A. Demiroren and U. Yilmaz, "Analysis of change in electric energy cost with using renewable energy sources in Gökceada, Turkey: An island example," Renew. Sustain. Energy Rev., vol. 14, no. 1, pp. 323-333, 2010.

[11] K. Y. Lau, M. F. M. Yousof, S. N. M. Arshad, M. Anwari, and a. H. M. Yatim, "Performance analysis of hybrid photovoltaic/diesel energy system under Malaysian conditions," Energy, vol. 35, no. 8, pp. 3245$3255,2010$.
[12] O. Hafez and K. Bhattacharya, "Optimal planning and design of a renewable energy based supply system for microgrids," Renew. Energy, vol. 45, pp. 7-15, 2012.

[13] L. Montuori, M. Alcázar-Ortega, C. Álvarez-Bel, and A. Domijan, "Integration of renewable energy in microgrids coordinated with demand response resources: Economic evaluation of a biomass gasification plant by Homer Simulator," Appl. Energy, vol. 132, pp. 15-22, 2014.

[14] INEC, "Total de viviendas particulares con personas presentes por procedencia de luz eléctrica, según provincia, cantón y parroquia de empadronamiento", $2010 . \quad$ [Online]. Available: http://www.ecuadorencifras.gob.ec/informacion-censal-cantonal/

[15] J. Maldonado, O. Álvarez, T. Montaño and J. Solano, "Desarrollo de energías renovables a pequeña escala en los sectores rurales de la provincia de Loja", Revista Tecnológica ESPOL - RTE, vol. 27, no. 1, pp. 59-69, 2014.

[16] ARCONEL, "Estadística Sector Eléctrico Ecuatoriano 2014 C," Quito, 2014.

[17] MEER, “Atlas solares y Eólico del Ecuador", 2016. [Online]. Available: http://www.energia.gob.ec/biblioteca/

[18] C. Pavón, J. Barzola, F. Cabrera, C. Briones, and M. Espinoza, "Fuentes de Energías Renovables como potencial de producción eléctrica en zonas rurales del Ecuador," in Proceedings of the Thirteenth Latin American and Caribbean Conference for Engineering and Technology, 2015, pp. 12.

[19] C. Pavón and J. Barzola, "Estimación de la demanda energética mensual mediante encuesta aplicada en la Provincia de Santa Elena," Rev. Cient. Yachana, vol. 4, no. 2, in press.

[20] R. Sen and S. C. Bhattacharyya, "Off-grid electricity generation with renewable energy technologies in India: An application of HOMER," Renew. Energy, vol. 62, pp. 388-398, 2014.

[21] K. Y. Lau, M. F. M. Yousof, S. N. M. Arshad, M. Anwari, and a. H. M. Yatim, "Performance analysis of hybrid photovoltaic/diesel energy system under Malaysian conditions," Energy, vol. 35, no. 8, pp. 3245$3255,2010$.

[22] J. Barzola, “¿Es posible la Grid Parity en Ecuador?,” Rev. Tecnológica ESPOL - RTE, vol. 27, no. 1, pp. 30-39, 2014.

[23] J. Barzola, F. Cabrera, and M. Espinoza, "Test Results of a Mortar Made of Crushed Rice Husk Used for Housing Walls," in 13th LACCEI Annual International Conference, 2015, pp. 29-30.

[24] M. Kaltschmitt, W. Streicher, and A. Wiese, Renewable Energy: Technology, Economics and Environment. Berlin: Springer, 2007.

[25] D. Connolly, H. Lund, B. V. Mathiesen, and M. Leahy, "A review of computer tools for analysing the integration of renewable energy into various energy systems," Appl. Energy, vol. 87, no. 4, pp. 1059-1082, 2010.

[26] T. Lambert, P. Gilman, and P. Lilienthal, "Micropower System Modeling with Homer," in Integration of Alternative Sources of Energy, 2006, pp. 379-418.

[27] S.O. Ani, "Low Cost Small Wind Turbine Generators for Developing Countries," Technische Universiteit Delft, 2013.

[28] Banco Central del Ecuador, "Indicadores Económicos," 2016. [Online]. Available: http://www.bce.fin.ec/.

[29] CONELEC, Tarifas eléctricas en Ecuador, no. Resolución N.- 043/11. Ecuador, 2011, pp. 1-4.

[30] D. Feldman, G. Barbose, R. Margolis, D. Chung, R. Fu, J. Seel, C. Davidson, and R. Wiser, "Photovoltaic System Pricing Trends Historical, Recent, and Near-Term Projections," NREL/PR-6A20-64898, 2015.

14 ${ }^{\text {th }}$ LACCEI International Multi-Conference for Engineering, Education, and Technology: "Engineering Innovations for Global Sustainability", 20-22 July 2016, San José, Costa Rica. 